NOTICE: this is the author's version of a work that was accepted for publication in Tourism Management. Changes resulting from the publishing process, such as peer review, editing, corrections, structural formatting, and other quality control mechanisms may not be reflected in this document. Changes may have been made to this work since it was submitted for publication. A definitive version was subsequently published in Tourism Management, Vol. 46 (2015). DOI: 10.1016/j.tourman.2014.08.013 


\title{
Incorporating the winescape into the theory of planned behaviour: Examining 'new world' wineries
}

\begin{abstract}
The current study sets out to examine the winescape for its effects on wine tourist behaviour. In doing so, an empirical winescape scale is introduced to an established decision-making model, the theory of planned behaviour. A total of 1,135 responses were collected through a survey that was self-administered to wine tourists across four wineries in Australia and the USA. Structural equation modelling suggested that winescape service staff and complementary product had significant effects on wine tourist attitude toward the winery, making them instrumental in wine tourist decision-making. Winescape setting and wine value were also significant attributes in influencing wine tourist attitude. Findings provide greater insight into which winescape attributes are most critical in shaping wine tourist attitude and in turn, behavioural intention toward the winery. The research model offers an empirical decision-making framework that is easy to use and generalisable in wine tourism contexts.
\end{abstract}

Keywords: winescape; attitude; subjective norms; perceived behavioural control; revisit intention; willingness to recommend

\section{Introduction}

People have paid tribute to the grape and enjoyed its wine since the Neolithic period and beyond (McGovern, 2003). In 2012, wine produced in France and Italy, 'old world' wine economies accounted for 41,422 million hectares and 40,060 million hectares respectively. In the same year, wine produced in Australia and the USA, 'new world' wine economies accounted for 12,660 million hectares and 20,510 million hectares respectively (International Organisation of Vine and Wine, 2013). Visitation to wineries to experience wine-making and wine consumption in situ has become a tourism activity that offers visitors an "incentive to participate" (Marzo-Navarro \& Pedraja-Iglesias, 2012, p. 134). In fact, Hall et al. (2002, p. 3) have observed the phenomenon of wine tourism as "visitation to vineyards, wineries, wine festivals and wine shows for which grape wine tasting and/or experiencing the attributes of a grape wine region are the prime motivating factors for visitors." Thus, a favourable wine tourist experience occurs when a wine tourist has a positive interaction with these wine attributes. 
Wine tourism affords several advantages. From a macro perspective, it contributes to sustainable regional development (Carlsen, 2004; Gammack, 2006). Skinner (2000) has observed that as wine regions become increasingly involved or even reliant on wine tourism, the need to sustain tourism as an economic resource is crucial. According to Poitras and Getz (2006), sustainable wine tourism takes into account the identification and management of unique issues related to the infrastructure and resources used, specific forms of wine tourism development and detailed impacts caused by wine tourism. From a micro perspective, wine tourism benefits wine producers with cellar doors where the wines they produce are showcased and sold. For instance, in the Margaret River wine region of Western Australia, cellar door sales represent $34 \%$ of total wine sales, with $15 \%$ of wineries dependent on cellar door sales for over $80 \%$ of their sales revenue (O’Neill, Palmer, \& Charters, 2002). Thus, delivering a positive wine tourist experience at the cellar door is crucial. First, it increases brand awareness and allows the wine tourist to engage with the winery, enabling wine producers to communicate their history and present their brand's product portfolio. Second, it impacts on post-visit purchase behaviour (Johnson \& Bruwer, 2007; O’Neill, Palmer, \& Charters, 2002), instigating repeat wine purchases and increasing sales for the winery.

From an academic perspective, interest in wine tourism can provide in-depth knowledge of wine tourist characteristics, motives and preferences that determine decisionmaking (Marzo-Navarro \& Pedraja-Iglesias, 2010). Clearly, a positive cellar door experience can shape favourable wine tourist attitude toward the cellar door and in turn, behavioural intention such as willingness to revisit the winery and recommend it to others. The phenomenon of experiencing the grape wine environment or 'winescape' was first introduced by Peters (1997, p. 124) when he referred to it as a cultural/viticultural landscape with "a winsome combination of vineyards, wineries and supporting activities necessary for modern production." Since then, over 30 academic publications have made reference to the winescape 
(e.g. Bruwer \& Alant, 2009; Getz et al., 1999; Hall et al., 2002; Johnson \& Bruwer, 2007; Mitchell, Charters, \& Albrecht, 2012; Sharples, 2002; Sparks, 2007; Telfer, 2000).

Despite many publications devoted to the winescape, the wine tourism literature remains fragmented and in its infancy stage. These limitations may be summarised into two areas. First, varying winescape conceptualisations with scant theoretical underpinnings have given rise to crude operationalisations of the construct (Bruwer \& Lesschaeve, 2012). This has resulted in a lack of consensus about how the winescape is perceived and what attributes it encapsulates (Hall et al., 2002). Second, limited empirical studies have examined causal relationships between the winescape and wine tourist behavioural intention. For instance, Getz and Brown (2006[b]) have identified an a priori list of supply-related winescape attributes but have not proceeded to test the effects of these attributes on wine tourist behavioural intention. Further, Lockshin and Corsi (2012) have observed that the buying behaviour of wine tourists in situ is an under researched area that requires consideration.

The current study aims to address these identified gaps in the literature. To attend to the first gap, it introduces servicescape theory (Bitner, 1992) that underpins conceptualisation of the winescape and its attributes. Then, it identifies and clarifies the diverse approaches adopted in winescape definitions and offers an approach which can be commonly adopted in future research. To address the second gap, the study introduces an empirical winescape scale developed by Thomas, Quintal, and Phau (2010[a], 2010[b], 2011) to an established decisionmaking model, the theory of planned behaviour (TPB). While the said scale has been validated in Australia, the current study is the first to replicate the scale in the USA and the first to utilise the TPB in a wine tourism context in the USA. Introducing the winescape scale to the TPB offers a generalisable framework that can be commonly utilised to predict wine tourist behavioural intention. 


\section{Literature review}

\subsection{The winescape}

The servicescape was introduced by Bitner (1992, p. 65) to the discipline of services marketing as "the dimensions of the physical surroundings (of a service environment)... that can be controlled by the firm to enhance (or constrain) employee and customer actions." In Bitner's (1992) seminal study, the servicescape comprises three key dimensions: (1) ambient conditions; (2) spatial layout and functionality; and (3) signs, symbols and artefacts. According to the author, these attributes come together to affect mood state and attitude in customers and employees, leading to either approach or avoidance behaviours.

Servicescape theory has underpinned a range of studies across contexts such as banks (e.g. Reimer \& Kuehn, 2005), retail settings (e.g. Wirtz, Mattila, \& Tan, 2007), sports stadiums (e.g. Wakefield \& Blodgett, 1999), airport terminals, universities, hospitals (e.g. Newman, 2007), restaurants, bars (e.g. Kim \& Moon, 2009) and casinos (e.g. Lucas, 2003). In fact, some empirical studies have extended servicescape theory to more specific contexts that have unique attributes, resulting in the shipscape (Kwortnik, 2008), the festivalscape (Lee et al., 2008) and the musicscape (Oakes \& North, 2008). For instance, Kwortnik's (2008) shipscape has identified: (1) the natural environment (sea); (2) ambient conditions (scents, sounds, cleanliness and lighting); (3) design factors (decor, colour schemes, furnishings and layout); and (4) social factors (crowds, queuing and service staff interactions) for their influence on passengers' attitude toward their cruise experience. Alternatively, Lee et al.'s festivascape (2008) has observed: (1) program content; (2) staff interactions; (3) festival facilities; (4) food options; (5) souvenirs; (6) convenience; and (7) information availability that affect festival goers' satisfaction. This suggests there is potential to extend servicescape theory to the winery's specific context of the winescape. 
Since Peters' (1997) seminal paper, the winescape has been conceptualised from both general and specific perspectives. General conceptualisations include Hall et al.'s (2002, p. 4) reference to "attributes of a grape wine region" and Douglas, Douglas and Derrett's (2001, p. 313) "physical, social and cultural dimensions of the winescape and its components." Specific conceptualisations include Telfer's (2000, p. 73) reference to "three main elements; the presence of vineyards, the wine-making activity and the wineries where the wine is produced and stored" and Johnson and Bruwer's (2007, p. 277) "interplay of; vineyards, wineries and other physical structures, wines, natural landscape and setting, people and; heritage, towns and their architecture and artefacts within them."

The winescape has also been conceptualised from two approaches. The macro approach views the winescape as a wine region or wine route and is most predominate in wine tourism literature (e.g. Getz \& Brown, 2006[a]). However, this approach presents several limitations. First, it takes into account many factors such as history, culture, facilities, amenities, layout and signage, resulting in too broad definitions of the winescape. Second, its wide regional scope makes it difficult to identify and measure specific winescape attributes for their influence on wine tourist attitude and subsequent behavioural intention, resulting in few empirical studies of the winescape. The micro approach focuses on the winescape as the environment at a specific winery (e.g. Carmichael, 2005). Adopting this approach offers some advantages. First, it provides focus to a wine tourist experience in a specific winery service environment, defining parameters for conceptual and operational definitions of the winescape. Second, it allows specific winescape attributes to be examined for their effects in an identified environment, enabling an empirical study to be conducted. In adopting the micro approach, the current study adapts Johnson and Bruwer's (2007) definition and refers to the winescape as the interplay of: natural landscape and setting; heritage architecture and 
artefacts within a winery; a winery's vineyard, cellar door and wines; complementary products and services; signage; and people at a winery.

Limited empirical studies that operationalise the wine tourism environment exist in the wine tourism literature. Two exceptions to these studies include Sparks (2007) and Thomas, Quintal and Phau (2010[a], 2010[b], 2011). Sparks' (2007) extensive study of wine tourists in Australia has operationalised the wine tourism product as the: (1) wine destination; (2) core wine experience; (3) food and wine; and (4) personal development. However, Sparks' (2007) study has some limitations. First, it adopts both the macro and micro approaches by considering the general wine region (e.g. wine destination) and specific winery attributes (e.g. core wine experience). Second, it makes no distinction between the 'pull' factors or supply-related attributes (e.g. food and wine) and 'push' factors or demand-related attributes (e.g. personal development) of the wine tourism product. This makes it difficult to identify and measure specific winescape attributes for their influence on wine tourist attitude and subsequent behavioural intention.

Thomas, Quintal, and Phau's (2010[a], 2010[b], 2011) study has operationalised the supply-related attributes of the winescape as the: (1) setting; (2) atmospherics; (3) wine quality; (4) wine value; (5) wine complementary product; (6) signage; and (7) wine service staff. Their resultant 20 -item measure followed scale development procedures as suggested by Churchill (1979) and De Vellis (2003) and demonstrated reliability, validity and configural measurement invariance across wineries in Australia. For these reasons, this scale is utilised in the current study to provide greater insight into how specific winescape attributes can directly predict wine tourist attitude and indirectly predict behavioural intention. 


\subsection{The theory of planned behaviour}

The theory of planned behaviour (TPB) was introduced by Ajzen (1991) to the discipline of psychology so as to explain the decision-making processes of individuals. Central to the TBP is an individual's intention to perform a given behaviour. Behavioural intention refers to an indication of an individual's readiness to perform a given behaviour. This intention is determined by three conceptually independent constructs, namely, attitude, subjective norms and perceived behavioural control. Attitude refers an individual's positive (negative) evaluation of self-performance of the particular behaviour. Subjective norms is an individual's perception of social normative pressures that they should (should not) perform such behaviour. Perceived behavioural control is an individual's beliefs about the presence of factors that may facilitate (impede) performance of the behaviour. In Ajzen's (2001) subsequent review of behaviour, the author has reinforced the utility of the TPB to predict behavioural intention, which in turn, has been useful in predicting actual behaviour. Actual behaviour refers to an individual's observable response in a given situation with respect to a given target (Ajzen \& Fishbein, 1980).

The TPB has been applied across a range of disciplines such as social psychology (e.g. Armitage \& Conner, 2001), health psychology (e.g. French \& Hankins, 2003), marketing (e.g. Hoffman \& Novak, 1996), environmental science (e.g. Bernath \& Roschewitz, 2008), tourism (e.g. Hsu \& Huang, 2012; Lam \& Hsu, 2004; Quintal, Lee, \& Soutar, 2010) and wine tourism (e.g. Sparks, 2007). Such studies have examined the TPB constructs in diverse contexts such as urban forest benefits (Bernath \& Roschewitz, 2008), healthy eating (Astrom \& Rise, 2001), motivation to visit travel destinations (Hsu \& Huang, 2012), risk in visiting travel destinations (Quintal, Lee, \& Soutar, 2010), green hotel choices (Han, Hsu, \& Sheu, 2010) and wine holiday choices (Sparks, 2007). 
Generally, findings for these studies have reported the relevance of the TPB in explaining behavioural intention. For instance, in the health discipline, Francis et al. (2004) have conducted a review of 222 medical and health-related studies that have utilised the TPB since 1985. The authors have concluded that the TPB is a robust predictor of intention in medical and health-related contexts. Likewise, in the tourism discipline, Han, Hsu and Sheu (2010) as well as Quintal, Lee, and Soutar (2010) have concluded that favourable tourist attitude, higher subjective norms and greater perceived behavioural control are positive antecedents to behavioural intention to visit a destination.

More specifically related to wine tourism, Sparks (2007, p. 1182) has observed that in accordance with TPB theory, "it is fundamental to have an understanding of the evaluation consumers place on attributes of a product" since this influences behavioural intention. In this context, behavioural intention is the "relationship of the tourist's general level of interest in wine to their immediate purpose of visiting a specific winery" (Charters \& Ali-Knight, 2002, p. 317). Sparks' (2007) application of the TPB to explain wine tourist decision-making supports the tenets that favourable attitude, higher subject norms and perceived behavioural control are positive predictors of behavioural intention toward a winery.

Given the current study's focus on the winescape, any insight into how individuals evaluate the wine tourist experience will be critical to wine tourism. Clearly, a wine tourist who develops beliefs about the winescape attributes will form an attitudinal judgement toward a particular behaviour associated with the winescape. This attitudinal judgement will drive the wine tourist to evaluate their behavioural intention and subsequent behaviour toward the winescape. Consequently, it is envisaged that the current study's use of the TPB will add to the collective understanding of decision-making in wine tourism contexts in Australia and the USA. 


\section{Research model and hypotheses}

In the current study, the winescape is conceptualised as encapsulating seven supplyrelated attributes: (1) setting; (2) atmospherics; (3) wine quality; (4) wine value; (5) wine complementary product; (6) signage; and (7) wine service staff (Thomas, Quintal, \& Phau, $2010[\mathrm{a}], 2010[\mathrm{~b}], 2011)$. These winescape attributes are introduced to the theory of planned behaviour (TPB). As can be seen in Figure 1, the research model tests the winescape attributes for their ability to directly predict wine tourist attitude and indirectly predict behavioural intention, namely, willingness to revisit and recommend the winery.

Winescape setting is conceptualised as the environment around the winery such as the natural landscape, beautiful surrounds and vineyards that create ambience (Thomas, Quintal, \& Phau, 2010[a], 2010[b], 2011). In the wine tourism literature, there is support for the effect winescape setting has on wine tourist attitude. For instance, Carmichael (2005) has identified the rural landscape as a key driver of wine tourists' favourable assessments of the Niagara wine region in Canada. It has been suggested that attractive views and natural setting affect wine tourists' positive evaluations of a winescape (Griffin \& Loersch, 2006). Likewise, Sparks' (2007) study that utilises the TPB has noted the beautiful surroundings as a positive predictor of wine tourist attitude toward taking a wine holiday. Consequently:

Hla: Winescape setting will have a positive effect on wine tourist attitude toward the winery.

Winescape atmospherics refers to the features and quality of the built environment such as the interior and exterior design of the winery facilities, building materials, furnishings, heritage artefacts, displays or symbols that create identity (Thomas, Quintal, \& Phau, 2010[a], 2010[b], 2011). It is likely that winescape atmospherics will influence wine tourist attitude. For instance, Griffin and Loersch (2006) have adapted the SERVQUAL scale 
and have noted that the built environment affected wine tourists' favourable evaluations of the winery experience. Further, Pan, Su and Chiang (2008) have examined the interior and exterior design of the built environment and suggested that design had a positive relationship with wine tourist attitude. In Hall et al.'s (2002) observation of heritage artefacts, the authors have identified historical displays as a secondary attribute that influenced wine tourist attitude. Finally, Dodd (1995, 2000) has reported that displays or symbols favourably impacted on wine tourist attitude. Therefore:

H1b: Winescape atmospherics will have a positive effect on wine tourist attitude toward the winery.

Winescape wine quality is defined as the quality of the wines produced at the winery and delivered at its cellar door (Thomas, Quintal, \& Phau, 2010[a], 2010[b], 2011). The impact winescape wine quality has on wine tourist attitude is demonstrated in the wine tourism literature. For instance, Dodd (2000) has observed that wine quality and wine taste had a positive effect on wine tourist attitude toward the winery. Similarly, the SERVQUAL scale has been adapted to a winery context and has highlighted the importance of wine products in evaluating the overall winery experience (O’Neill, Palmer, \& Charters, 2002). Thus:

H1c: Winescape wine quality will have a positive effect on wine tourist attitude toward the winery.

Winescape wine value is conceptualised as the value of the wines produced at the winery and delivered at its cellar door (Thomas, Quintal, \& Phau, 2010[a], 2010[b], 2011). In the wine tourism literature, there is support for the effect that winescape wine value has on wine tourist attitude. For instance, Dodd and Gustafson (1997) and Bruwer and Alant (2009) have observed that the affordable price of wines at a cellar door had a positive influence on 
wine tourist attitude. Likewise, Roberts and Sparks (2006) have concluded that value-formoney wines were essential attributes of a wine region experience for the wine tourist. Consequently:

Hld: Winescape wine value will have a positive effect on wine tourist attitude toward the winery.

Winescape complementary product refers to the variety of ancillary services of the winery such as dining facilities, accommodation, local produce and crafts, art, attractions, shopping, entertainment and activities that support the primary wine tourist experience (Thomas, Quintal, \& Phau, 2010[a], 2010[b], 2011). It is likely that winescape complementary product will influence wine tourist attitude. For instance, fine cuisine (Carlsen \& Dowling, 2001), food (Mitchell \& Hall, 2004) and dining (Carmichael, 2005) have been identified as key attributes for a favourable winery experience. Hall et al. (2002) and Carlsen and Dowling (2001) have observed that accommodation was important for positive wine tourist evaluations. Further, Roberts and Sparks (2006) have cited visiting local producers and sampling their cheese and olive oil offerings were key enhancers to the wine tourist experience in Australia. Wine tourists have reported that special arts and handicrafts were cultural activities that influenced them to visit a winery (Cohen \& Ben-Nun, 2009; Koch, Martin, \& Nash, 2013). Finally, a range of attractions and activities, not directly related to the main activity of wineries, such as shopping (Carmichael, 2005) and entertainment (Bruwer, 2003) were suggested to affect favourable perception of the winery's offering. Therefore:

Hle: Winescape complementary product will have a positive effect on wine tourist attitude toward the winery. 
Winescape signage is defined as the use of promotion materials that explain to the wine tourists their role in the winery, direct them around the winery and communicate the winery's desired brand image (Thomas, Quintal, \& Phau, 2010[a], 2010[b], 2011). The impact winescape signage has on wine tourist attitude is demonstrated in the wine tourism literature. For instance, Griffin and Loersch's (2006) study of wineries has reported that adequate and well located directional signage as well as informative tasting notes resulted in positive wine tourist attitude toward the wineries. Getz and Brown (2006[b]) have highlighted the importance of branding a wine destination and using consistent images and messages in information offices, brochures, signposts and signs to convey brand image and influence behaviour. Thus:

H1f: Winescape signage will have a positive effect on wine tourist attitude toward the winery.

Winescape service staff is conceptualised as the winery staff's knowledge and personal skills that enhance the quality of their interaction with the wine tourist and enable the wine tourist to fulfil their desired visitation goals (Thomas, Quintal, \& Phau, 2010[a], 2010[b], 2011). In the wine tourism literature, there is support for the effect winescape service staff has on wine tourist attitude. For instance, knowledgeable cellar door staff had positive effect on wine tourist attitude toward the winery (Dodd 2000). Personal skills such as being friendly, understanding and attentive contributed toward a quality service delivery that influenced favourable wine tourist evaluations of the cellar door (Griffin \& Loersch, 2006; O’Neill, Palmer, \& Charters, 2002). Consequently:

H1g: Winescape service staff will have a positive effect on wine tourist attitude toward the winery.

\section{<Insert Figure 1 here>}


According to the TPB (Ajzen, 1991) and attitude theory (Ajzen \& Fishbein, 1980), an individual's attitude will affect their behavioural intention such as their willingness to revisit. For instance, Ryu and Jang (2007) have observed that pleasurable and arousing evaluations of a fine dining restaurant generated repeat visitation to the restaurant. Likewise, tourists' favourable evaluations of a destination have been found to positively influence their intention to revisit the destination (Chen \& Tsai, 2007; Quintal \& Polczynski, 2010). Lee and Chang's (2012) study of wine tourists in Taiwan have concluded that positive evaluations of a winery generated intention to revisit the winery. Therefore:

H2a: Favourable attitude toward the winery will have a positive effect on wine tourist willingness to revisit the winery.

Similarly, from the above two theories, attitude will influence behavioural intention such as willingness to recommend. For instance, patrons who enjoyed a pleasurable experience at a fine dining restaurant had favourable evaluations and were more willing to recommend it to others (Ryu \& Jang, 2007). In fact, it has been suggested that positive attitude played a significant role in negating unfavourable word-of-mouth behaviour toward Chinese restaurants (Cheng, Lam, \& Hsu, 2005). Tourists' favourable evaluations of their experience at a destination positively affected their willingness to recommend it (Yoon \& Uysal, 2005). Gill, Byslma and Ouschan's (2007) study of wine tourists in Australia have reported that positive evaluations of a winery created willingness to say positive things about the winery and its products to friends and relatives. Thus:

H2b: Favourable attitude toward the winery will have a positive effect on wine tourist willingness to recommend the winery.

As underpinned by the TPB (Ajzen, 1991) and social identity theory (Tajfel, 1979; Trepte, 2006), an individual's subjective norms will impact on their behavioural intention 
such as their willingness to revisit. For instance, Han, Hsu and Sheu's (2010) study of ecofriendly resorts has reported that subjective norms had a positive influence on intention to visit the resorts. Likewise, Sparks and Pan (2009) and Quintal, Lee and Soutar (2010) have noted that subjective norms favourably affected Chinese tourists' intention to visit Australia as a holiday destination. Sparks (2007) has also concluded that subjective norms had a positive effect on potential wine tourists' intention to take a wine holiday. Consequently:

H3a: Higher subjective norms will have a positive effect on wine tourist willingness to revisit the winery.

Similarly, based on the above two theories, social norms will affect behavioural intention such as willingness to recommend. For instance, Cheng, Lam and Hsu's (2005, 2006) studies of negative behavioural intention toward restaurants have observed that subjective norms positively influenced patrons' intention to spread favourable word-ofmouth. Further, Loda, Norman and Backman (2007) have suggested that subjective norms in the form of advertising and public relations had a significant effect on travellers' willingness to recommend holiday destinations to their friends. Therefore:

H3b: Higher subjective norms will have a positive effect on wine tourist willingness to recommend the winery.

According to the TPB (Ajzen, 1991) and self-efficacy theory (Bandura, 2010), an individual's perceived behavioural control will influence their behavioural intention such as their willingness to revisit. For instance, Han, Hsu and Sheu's (2010) study of eco-friendly resorts has reported that perceived behavioural control had a positive influence on intention to visit the resorts. Further, Sparks and Pan (2009) and Quintal, Lee and Soutar (2010) have observed that perceived behavioural control had a favourable effect on Chinese tourists' 
intention to visit Australia. Sparks (2007) has also reported that perceived behavioural control produced a positive impact on potential wine tourists' intention to take a wine holiday. Thus:

H4a: Higher perceived behavioural control will have a positive effect on wine tourist willingness to revisit the winery.

Similarly, based on the above two theories, perceived behavioural control will impact on behavioural intention such as willingness to recommend. For instance, Cheng, Lam and Hsu's $(2005,2006)$ studies of negative behavioural intention toward restaurants have suggested that higher perceived behavioural control negated patrons' intention to spread unfavourable word-of-mouth. Consequently:

H4b: Higher perceived behavioural control will have a positive effect on wine tourist willingness to recommend the winery.

\section{Methodology}

\subsection{Survey instrument and measures}

A self-administered pen and paper survey was used in the current study. Measures for the winescape scale were developed by Thomas, Quintal and Phau (2010[a], 2010[b], 2011). Initially, the authors had identified 10 factors in their winescape scale which were further refined and tested for their reliability and validity and reduced to seven factors. We have obtained and utilised their final seven-factor, 20-item scale, as can be seen in Appendix 1, which will be published in due course. Measures for the theory of planned behaviour (TPB) constructs were selected from existing scales (see Ajzen \& Driver, 1992; Bagozzi, Dholakia, \& Basuroy, 2003; Quintal, Lee, \& Soutar, 2010; Sparks, 2007) for their reliability (>0.72) (Hair et al., 2010) and relevance to the wine tourism context. For all constructs, a seven-point Likert scale was adopted, ranging from 1 for "strongly disagree" to 7 for "strongly agree," 
with the exception being the attitude construct which was measured with a semantic bi-polar scale. 


\subsection{Sampling frame}

The survey instrument was self-administered in situ to wine tourists at three individual wineries in three wine regions across three states in Australia between February 2012 and December 2012.

\section{<Insert Picture 1 here>}

The three studies adopted a micro perspective that was winery-specific so that the winescape attributes could be examined for their effects in an identified winery. Study 1's winery is located at the Swan Valley in Western Australia as can be seen in Picture 1. Study 2's winery is located at the Yarra Valley in Victoria. Study 3's winery is located at the Barossa Valley in South Australia as can be seen in Picture 2.

\section{<Insert Picture 2 here>}

Each wine region in its respective Australian state accounts for the production of a sizeable volume of quality wines. In these three studies, a total of 952 completed surveys were collected and 790 were usable, resulting in a response rate of $82 \%$. Missing data was replaced with imputed mean scores. The three studies were conducted to validate the research model's applicability across Australia.

Then, the survey instrument was self-administered to an online panel of consumers who had previously visited a winery at the Napa Valley in the USA in June 2013. Again, the study adopted a micro perspective that was winery-specific since respondents were asked to select one winery and confine their responses to the specific winery. In this study, a total of 345 completed surveys were collected and all were usable, with no missing data observed. The study was administered to validate the research model's generalisability to the USA and 
other 'new world' wine economies. Data collection for the four studies is summarised in Table 1.

\section{<Insert Table 1 here $>$}

\subsection{Sampling method}

A convenience sampling approach using wine tourists was adopted for the four studies conducted in Australia and the USA. In the three Australian studies, the samples were collected using an intercept approach. In adopting this approach, the researchers randomly approached and intercepted wine tourists as they exited a selected winery to elicit their response to the winescape. This allowed respondents to reflect directly on the cellar door experience while it was still fresh in their minds. As an incentive for wine tourists to participate, a prize draw with a chance to win a case of selected wines was used for each of the three Australian studies. In the USA study, the sample was randomly drawn from an online consumer panel that had agreed to participate and were paid (in points) for their time.

\section{Results}

\subsection{Descriptive analysis and mean differences}

The winescape attributes and the theory of planned behaviour (TPB) constructs were examined using descriptive statistics with SPSS 20 as can be seen in Table 2. Independent groups t-test demonstrated that the average scores for the majority of the winescape attributes were highest in Study 4 and demonstrated significant differences with Studies 1, 2 and 3. Since Study 4 asked respondents about their visit to a winery in Napa Valley, respondents may have identified with their most favourite winery when rating its winescape attributes, accounting for the significantly higher scores. An exception was the average scores for winescape setting in Study $4(\mathrm{t}=6.16)$ and Study $1 \quad(\mathrm{t}=6.18)$, suggesting that the natural 
landscape was critical for respondents in both studies. Given that Study 1's winery boasts a picturesque backdrop and is a popular venue for weddings and corporate functions, this finding is not unexpected. Another exception was the average scores for winescape service staff in Study $4(\mathrm{t}=6.19)$ and Study $3(\mathrm{t}=6.18)$, suggesting that respondents in both studies shared similar high perceptions of service staff at the winery.

\section{<Insert Table 2 here $>$}

Construct reliability and average variance extracted scores were calculated using standardised parameter estimates scores derived from confirmatory factor analysis with AMOS 20 as can be seen in Table 2. Across the four samples, construct reliabilities for all constructs were acceptable ( $\geq 0.70$ ) (Hair et al., 2010), suggesting the seven winescape factors had stable dimensions. Average variance extracted scores of all constructs across the four samples were high $(\geq 0.50)$, suggesting convergent validity (Fornell \& Larcker, 1981). An exception to Fornell and Larcker's (1981) test was winescape complementary product in Study 2 (0.45). However, since the magnitude, direction and statistical significance of its parameter estimates were positive and theoretically consistent, this suggested some convergent validity (Steenkamp \& van Trijp, 1991) and the attribute was accepted. As can be seen in Table 3, correlations between all constructs were low $(\leq 0.80)$, suggesting discriminant validity (Bagozzi \& Heatherton, 1994). Across the four samples, average variance extracted scores for all constructs $(0.45-0.89)$ exceeded the squared correlations between any two constructs (0.001-0.42), also suggesting discriminant validity (Fornell \& Larcker, 1981).

\section{<Insert Table 3 here>}

\subsection{Hypotheses testing}


The hypothesised relationships identified in the research model were tested using path analysis with AMOS 20 and the results can be seen in Table 4. The goodness-of-fit indices for each of the four samples was acceptable $\left(\chi^{2} / d f \leq 3.0\right.$; RMSEA $\left.\leq 0.08 ; \mathrm{CFI} \geq 0.90\right)$. Although the GFI and NFI did not exceed the critical level of 0.90 in some models, the models were deemed acceptable because they met the other goodness-of-fit criteria.

Winescape setting had a significant and positive effect on wine tourist attitude toward the winery in the pooled sample $(\beta=0.13, p=0.001)$ and Study $4(\beta=0.33, p=0.001)$, partly supporting Hla. In line with wine tourism studies (e.g. Carmichael, 2005; Griffin \& Loersch, 2006; Sparks, 2007), this finding suggests that the natural surroundings plays a positive role in shaping attitude toward the winery.

Winescape atmospherics did not produce a significant effect on wine tourist attitude toward the winery in the pooled and individual samples, which did not support $H 1 b$. At face value, this finding is not supported by wine tourism studies (e.g. Griffin \& Loersch, 2006; O’Neill, Palmer, \& Charters, 2002; Pan, Su, \& Chiang, 2008). However, some explanation is offered for the inconsistency in findings. In these studies, atmospherics refers to the aesthetics of the built environment, whereas in the current study, winescape atmospherics refers mainly to the heritage aspects of the built environment. Since Australian and American wineries are relatively young, it is possible respondents did not perceive heritage in the wineries' architecture, resulting in the non-significant effect.

Winescape wine quality did not have a significant effect on wine tourist attitude toward the winery in the pooled and individual samples, which did not support H1c. It would appear that other wine tourism studies do not support this conclusion (e.g. Dodd, 2000; Dodd \& Gustafson, 1997). However, the inconsistency in findings may be plausible here. Since the sampling frame for each study was drawn from a general population of wine tourists with 
varying knowledge of wine, it may have been difficult for some to assess the quality of the wines offered at the winery and form an attitude toward the winery in situ.

Winescape wine value produced a significant and positive effect on wine tourist attitude toward the winery in the pooled sample $(\beta=0.08, p=0.05)$ and Study $3(\beta=0.17$, $p=0.05$ ), partly supporting $H 1 d$. Following other wine tourism studies, this finding reiterates that value-for-money wines play a positive role in shaping attitude toward the winery (e.g. Griffin \& Loersch, 2006; Roberts \& Sparks, 2006).

Winescape complementary product had a significant and positive effect on wine tourist attitude toward the winery in the pooled sample $(\beta=0.18, p=0.001)$; Study 1 ( $\beta=0.19$, $p=0.01)$; Study $2(\beta=0.24, p=0.05)$; and Study $3(\beta=0.27, p=0.001)$, partly supporting Hle. This finding is consistent with tourism studies which observe that complementary products/services is instrumental in developing positive attitude toward the winery (e.g. Albacete-Saez, Fuentes-Fuentes, \& Llorens-Montes, 2007; Gonzalez, Comesana, \& Brea, 2007; Hernandez Maestro, Munoz Gallego, \& Santos Reuejo, 2007). Clearly, winescape complementary product contributes to the holistic wine tourist experience in Australia. Conversely, winescape complementary product had a significant and negative effect on wine tourist attitude toward the winery in Study $4(\beta=-0.12, p=0.05)$, which did not support Hle. It is possible that at the Napa Valley in the USA, wine remains the central focus for wine tourists. Since the complementary product merely enhances experience with the core product, wine tourists may regard the complementary product as a winescape attribute that distracts from the core winery experience.

Winescape signage did not produce a significant effect on wine tourist attitude toward the winery in the pooled and individual samples, which did not support $H 1 f$. The services marketing literature postulates that the servicescape facilitates either functional or hedonic 
needs (e.g. Cockrill, Goode, \& Emberson, 2008). Signage in the servicescape is more important when addressing functional needs (Newman, 2007) and less important when addressing hedonic needs (Cockrill, Goode, \& Emberson, 2008). Since a winery is a service environment that facilitates fulfilment of hedonic needs, signage may be acknowledged as important when immediately required and not acknowledged after it has served its purpose. Indeed, this may be a winescape attribute that is taken for granted by the wine tourist.

Winescape service staff had a significant and positive effect on wine tourist attitude toward the winery in the pooled sample $(\beta=0.42, p=0.001)$; Study $1(\beta=0.39, p=0.001)$; Study $2(\beta=0.37, p=0.001) ;$ Study $3(\beta=0.30, p=0.01)$; and Study $4(\beta=0.57, p=0.001)$, supporting $H \mathrm{lg}$. In line with wine tourism studies, this finding suggests that good service is instrumental in developing positive attitude toward the winery (e.g. Dodd, 2000; Griffin \& Loersch, 2006; O’Neill, Palmer, \& Charters, 2002).

\section{<Insert Table 4 here>}

Wine tourist attitude toward the winery produced a significant and positive effect on intention to revisit the winery in the pooled sample $(\beta=0.41, p=0.001)$; Study $1(\beta=0.35$, $p=0.001)$; Study $2(\beta=0.51, p=0.001)$; Study $3(\beta=0.35, p=0.001)$; and Study $4(\beta=0.45$, $p=0.001$ ), supporting $H 2 a$. Following other tourism studies (e.g. Lee et al., 2008; Quintal \& Polczynski, 2010), this finding reiterates that positive attitude favourably affects revisit intention, making attitude's link to loyalty relevant in wine tourist decision-making.

Wine tourist attitude toward the winery had a significant and positive effect on willingness to recommend the winery in the pooled sample $(\beta=0.41, p=0.001)$; Study 1 $(\beta=0.35, p=0.001) ;$ Study $2(\beta=0.33, p=0.001) ;$ Study $3(\beta=0.39, p=0.001)$; and Study 4 ( $\beta=0.60, p=0.001$ ), supporting $H 2 b$. This finding is consistent with tourism studies which 
observe that positive attitude favourably affects willingness to recommend (e.g. Lee et al., 2008; Yoon \& Uysal, 2005), reiterating attitude's link to loyalty in wine tourism.

Wine tourist subjective norms produced a significant and positive effect on intention to revisit the winery in the pooled sample $(\beta=0.20, p=0.001)$; Study $1(\beta=0.11, p=0.05)$; Study $3(\beta=0.28, p=0.001)$; and Study $4(\beta=0.31, p=0.001)$, partly supporting $H 3 a$. In line with wine tourism studies (e.g. Sparks, 2007; Sparks \& Pan, 2009), this finding suggests that subjective norms has a positive effect on revisit intention.

Wine tourist subjective norms had a significant and positive effect on willingness to recommend the winery in the pooled sample $(\beta=0.24, p=0.001)$; Study $1(\beta=0.23, p=0.001)$; Study 3 ( $\beta=0.31, p=0.001)$; and Study $4(\beta=0.30, p=0.001)$, partly supporting $H 3 b$. Following other wine tourism studies (e.g. Sparks, 2007; Sparks \& Pan, 2009), this finding reiterates subjective norms' positive relationship with willingness to recommend.

Wine tourist perceived behavioural control produced a significant and positive effect on intention to revisit the winery in the pooled sample $(\beta=0.20, p=0.001)$; Study $1(\beta=0.27$, $p=0.001)$; Study $2(\beta=0.18, p=0.01)$; and Study $4(\beta=0.26, p=0.001)$, partly supporting $H 4 a$. This finding is consistent with wine tourism studies (e.g. Sparks, 2007; Sparks \& Pan, 2009) which observe that perceived behavioural control has a positive effect on revisit intention.

Finally, wine tourist perceived behavioural control had a significant and positive effect on willingness to recommend the winery in the pooled sample $(\beta=0.24, p=0.001)$; Study $1(\beta=0.21, p=0.01)$; Study $2(\beta=0.36, p=0.001)$; and Study $4(\beta=0.22, p=0.001)$, partly supporting $H 4 b$. In line with wine tourism studies (e.g. Sparks, 2007; Sparks \& Pan, 2009), this finding suggests perceived behavioural control's positive relationship with willingness to recommend. 


\section{Discussion}

The current study's first aim was to clarify conceptual and operational definitions of the winescape. In doing so, it conceptualised a micro approach that focused on the supplyrelated attributes of the winescape that could be specifically operationalised. The study's second aim was to introduce an empirical winescape measure to the theory of planned behaviour (TPB). This provided a wine tourist decision-making framework for directly predicting wine tourist attitude and indirectly predicting behavioural intention. Testing the research model across four studies conducted in Australia and the USA fulfilled these aims and responded to two key research gaps identified in the wine tourism literature.

Findings highlight which winescape attributes most directly influence wine tourist attitude and indirectly influence behavioural intention. Winescape service staff and complementary product had significant, positive effects and the highest beta scores with wine tourist attitude toward the winery in the pooled and individual samples. This suggested they were the two most critical winescape attributes in influencing wine tourist attitude toward the winery. An exception was the significant and negative effect that winescape complementary product had on wine tourist attitude toward the winery in Study 4. Clearly, in the USA, wine remains the central focus for wine tourists who appear to view the complementary product as a distraction from the core winery experience, whereas in Australia, the complementary product appears to contribute to the holistic wine tourist experience. Winescape setting and wine value produced significant, positive effects and high beta scores with wine tourist attitude toward the winery in the pooled sample and in Study 4 and Study 3 respectively. This suggested they were the third and fourth most critical winescape attributes in influencing wine tourist attitude toward the winery. 
Conversely, winescape atmospherics and wine quality did not have significant effects on wine tourist attitude toward the winery in the pooled and individual samples. It would appear that these attributes have less influence on wine tourist attitude toward the winery. However, across the four samples, the average scores for these two winescape attributes were above the scale mid-point of 4 , suggesting positive perceptions of these attributes in the winescape. Some explanations are offered here. Australia and the USA are 'new world' wine economies and do not have the same atmospheric proliferation of heritage-related architecture that can be found in 'old world' wine economies such as France, Italy and Spain. This could explain why winescape atmospherics did not produce a significant relationship with attitude toward the winery. Further, many wine tourists may not have sufficient experience in wine appreciation to evaluate the quality of a wine in situ. Their tendency to reserve judgement could explain why winescape wine quality did not significantly influence attitude toward the winery.

Findings highlight the influence wine tourist attitude, subjective norms and perceived behavioural control have on decision-making in the winescape. Clearly, some winescape attributes produced significant, positive effects that contributed to the high $R^{2} s$ for wine tourist attitude toward the winery in the pooled sample (0.40); Study 1 (0.36); Study 2 (0.28); Study 3 (0.43); and Study 4 (0.63). In turn, attitude, subjective norms and perceived behavioural control had significant, positive effects that produced acceptable $R^{2} s$ for willingness to revisit the winery in the pooled sample (0.32); Study $1(0.26)$; Study $2(0.33)$; Study 3 (0.25); and Study 4 (0.51). Additionally, attitude, subjective norms and perceived behavioural control produced significant, positive effects that contributed to the acceptable $R^{2} s$ for willingness to recommend the winery in the pooled sample $(0.37)$; Study $1(0.28)$; Study 2 (0.32); Study 3 (0.30); and Study 4 (0.65). This underlines the crucial role wine tourist attitude plays in mediating relationships between the winescape attributes and wine 
tourist behavioural intention. Further, the significant, positive effects subjective norms and perceived behavioural control had on willingness to revisit and recommend the winery in the pooled and individual samples validate the key roles both constructs play in the TPB model (Quintal, Soutar, \& Lee, 2010; Sparks, 2007). The significant and differential relationships these predictors have with behavioural intention can help to distinguish the wine tourist from the general tourist since the former demonstrates a greater level of interest and attitude toward wine that drives an immediate purpose for visiting a specific winery (Charters \& AliKnight, 2002).

Theoretically, the current study contributes to the literature by using servicescape theory to underpin conceptualisation of the winescape and its attributes. Then, it operationalises these attributes by adopting an empirical scale that encapsulates the supplyrelated attributes of wineries. This addresses the first research gap earlier identified in this paper. Next, the study introduces the winescape scale to the TPB. To the best of the authors' knowledge, the research model is the first to utilise an empirical framework that explains decision-making in a wine tourism context. Specifically, the framework examines the predictive power that the winescape attributes directly have on wine tourist attitude and indirectly have on behavioural intention. This responds to the second research gap identified earlier. Findings add to the body of empirical wine tourism research (e.g. Carmichael, 2005; Getz \& Brown, 2006[a]; Griffin \& Loersch, 2006; Sparks, 2007) and extend learning about which winescape attributes are most critical in shaping wine tourist attitude and in turn, behavioural intention toward the winery.

Operationally, the research model contributes to the wine industry by providing wine producers with the first wine tourist decision-making framework that is applicable to their business and easy to use. Wine producers will be able to administer the measure and evaluate 
how each supply-related attribute performs in the winescape. Since the majority of these attributes lie within the control of wine producers, findings will empower them to make decisions that improve their performance. Across the four samples, the average scores for willingness to revisit and recommend the winery were above the scale mid-point of 4 . It is in the best interest of wine producers to provide wine tourists with a positive winery experience that can shape favourable attitude and encourage behavioural intention.

Winescape service staff and complementary product are identified as the most influential winescape attributes that affect wine tourist attitude and subsequent behavioural intention toward the winery. From an operational perspective, this suggests that it is critical for wine producers to prioritise these two winescape attributes in their winery's offerings. This has two implications. First, winescape service staff requires training programs that address competencies essential in serving wine tourists. Also, human resource practices should be in place to ensure experienced staff is retained, reducing the cost of recruiting and training new ones. For instance, wine producers in South Australia who are committed to honing the professional skills of their winery staff can enlist the help of the South Australian Wine Industry Association (SAWIA). Established in 1840, SAWIA is the peak body representing the viticultural and winemaking interests of the state. A key function of the association is to provide industry training to its members. Current topics range from sustainable practices, employee relations as well as health and safety issues (http://www.winesa.asn.au/). Tangible feedback from wine producers on the critical need to upgrade the skills of their winescape service staff can help to drive policy on the content and delivery of training programs and the budgets allocated toward these initiatives.

Second, Australian wine producers must look to provide winescape complementary product that adds value to their core wine product. Cohen and Ben-Nun (2009) have 
highlighted the relationship between wine tourists' visit to a winery during the last two years with the cultural activities offered there. Presenting local produce, entertainment and gallery space can help to showcase a winery's unique offerings and give wine tourists an "incentive to participate in wine tourism" (Marzo-Navarro \& Pedraja-Iglesias, 2012, p. 134). From a branding perspective, this provides a platform for wine marketers to weave the wine producer's story into their brand and present a unique experience to wine tourists. For instance, the Leeuwin Estate in Margaret River, Western Australia presents a concert each year that is performed by world class entertainers. The Leeuwin Estate Concert Series has been running for 30 years and has developed an exclusive clientele that is attracted by the top billing concerts and the fine food and wines that the winery offers (Barrett, 2014).

\section{Limitations and future directions}

Key limitations to the study lie in its micro approach to the winescape and its focus on 'new world' wine economies. The adopted micro approach was winery-specific and restricted to assess the effects of the winescape attributes in an identified environment. Studies were conducted in Australia and the USA to focus on wine tourist behaviour in 'new world' wine economies. While the research model demonstrates generalisability across wineries in both these countries, the next step will be to adopt a macro approach to the winescape that is region-specific. This will ensure that the model is replicated for further validation across various wine regions and wine economies. Subsequent studies conducted in other "new world' wine economies such as Argentina, Chile and South Africa could highlight similarities in wine tourist experiences in these modern and developing wine economies. On the other hand, studies conducted in 'old world' wine economies such as France, Italy and Spain could highlight differences in wine tourist experiences in these traditional and developed wine economies. It may well be that winescape atmospherics which taps into the historical and 
heritage-related architecture of wineries and wine regions may play a significant and critical role in these 'old world' wine economies. Such comparative studies could help to establish the point of difference for each wine region and wine economy. Finally, a methodological limitation is the use of imputed mean scores to replace missing data in a variable. Although the method has the benefit of not changing the sample mean for that variable, it attenuates any correlations involving the imputed variable and impacts on multivariate analysis. Since this applied to approximately $5 \%$ of data in the current study's pooled sample, this impact was deemed to be acceptable.

Atmospherics has been identified as a critical dimension in the servicescape literature (e.g. Kwortnik, 2008; Lee et al., 2008; Oakes \& North, 2008). The attribute is viewed as an ambient dimension that taps into the sensory aspects of the servicescape (Bitner, 1992) and is particularly relevant in a tourism context where consuming sensory experiences is paramount. Since Thomas, Quintal, and Phau's (2010[a], 2010[b], 2011) winescape atmospherics attribute does not tap into this 'sensescape' aspect, it is feasible to probe into the multisensory aspects of this attribute for its relevance to the wine tourism context. A starting point would be to consider Heide and Grønhaug's (2006, p. 273) conceptual definition of atmosphere as the "air surrounding a sphere" which includes elements of the environment, other existing factors that contribute to the environment and the interaction between an individual and the environment. More recently, Agapito, Valle and Mendes' (2014, p. 233) study of sensory tourist experiences have identified the "rural experience" which taps into the light of the destination, the scent of fresh air and the taste of the local food. Undoubtedly, research that can clearly operationalise the notion of atmospherics can provide wine producers with insight into harnessing the benefits and managing the risks of investing in winescape atmosphere (Heide \& Grønhaug, 2006). 
A further recommendation is suggested for future winescape research. First, the winescape attributes, namely, service staff and complementary product are identified as the two most influential winescape attributes in shaping wine tourist attitude toward the winery. Therefore, it may be worthwhile to explore these two winescape attributes separately and in greater depth. This could develop collective understanding of precisely what aspects of these attributes affect wine tourist attitude and behavioural intention.

In summary, the current study sets out to utilise a scale that encapsulates the supplyrelated attributes of the winescape. This scale was introduced to the TPB model to test the ability of the winescape attributes to predict wine tourist decision-making across four wineries in Australia and the USA. Findings suggest that the research model offers the first empirically-tested decision-making framework that is applicable and generalisable across wineries in 'new world' wine economies. 


\section{References}

Agapito, D., Valle, P., \& Mendes, J. (2014). The sensory dimension of tourist experiences: capturing meaningful sensory-based themes in Southwest Portugal. Tourism Management, 42, 224-237.

Ajzen, I. (2001). Nature and operation of attitudes. Annual Review of Psychology, 52, 27-58.

Ajzen, I. (1991). The theory of planned behaviour. Organizational Behaviour and Human Decision Processes, 50(1), 179-211.

Ajzen, I., \& Driver, B. L. (1992). Contingent value measurement: on the nature and meaning of willingness to pay. Journal of Consumer Psychology, 1(4), 297-316.

Ajzen, I., \& Fishbein, M. (1980). Understanding attitudes and predicting social behaviour. Engle-wood-Cliffs, New Jersey: Prentice-Hall.

Albacete-Saez, C. A., Fuentes-Fuentes, M. M., \& Llorens-Montes, F. J. (2007). Service quality measurement in rural accommodation. Annals of Tourism Research, 34(1), 45-65.

Armitage, C. J., \& Conner, M. (2001). Efficacy of the theory of planned behaviour: a metaanalytic review. British Journal of Social Psychology, 40(4), 471-499.

Astrom, A. N., \& Rise, J. (2001). Young adults' intention to eat healthy food: extending the theory of planned behaviour. Psychology and Health, 16(2), 223-237.

Bagozzi, R., Dholakia, U., \& Basuroy, S. (2003). How effortful decisions get enacted: the motivating role of decision processes, desires, and anticipated emotions. Journal of Behavioural Decision Making, 16(4), 273-295.

Bagozzi, R. P., \& Heatherton, T. F. (1994). A general approach to representing multifaceted personality constructs: application to state self-esteem. Structural Equation Modelling, $1(1), 35-67$.

Bandura, A. (2010). Self-efficacy. Corsini Encyclopedia of Psychology, 1-3.

Barrett, J. (2014). How Margaret River winery Leeuwin Estate used a music concert to sell wine. Business Review Weekly, 17 February 2014.

Bernath, K., \& Roschewitz, A. (2008). Recreational benefits of urban forests: explaining visitors' willingness to pay in the context of the theory of planned behaviour. Journal of Environmental Management, 89, 155-166.

Bitner, M. J. (1992). Servicescapes: the impact of the physical surroundings on customers and employees. Journal of Marketing, 56(2), 57-71.

Bruwer, J. (2003). South African wine routes: some perspectives on the wine tourism industry's structural dimensions and wine tourism product. Tourism Management, 24(4), 423-435.

Bruwer, J., \& Alant, K. (2009). The hedonic nature of wine tourism consumption: an experiential view. International Journal of Wine Business Research, 21(3), 235-257.

Bruwer, J., \& Lesschaeve, I. (2012). Wine tourists' destination region brand image perception and antecedents: conceptualisation of a winescape framework. Journal of Travel and Tourism Marketing, 29(7), 611-628.

Carlsen, J. (2004). A review of global wine tourism research. Journal of Wine Research, 15(1), 5-13.

Carlsen, J., \& Dowling, R. (2001). Regional wine tourism: a plan of development for Western Australia. Tourism Recreation Research, 26(2), 45-59.

Carmichael, B. (2005). Understanding the wine tourism experience for winery visitors in the Niagara Region, Ontario, Canada. Tourism Geographies, 7(2), 185-204.

Charters, S., \& Ali-Knight, J. (2002). Who is the wine tourist? Tourism Management, 23(3), 311-319.

Chen, C. F., \& Tsai, D. (2007). How destination image and evaluative factors affect behavioural intentions. Tourism Management, 28(1), 1115-1122. 
Cheng, S., Lam, T., \& Hsu, C. H. C. (2006). Negative word-of-mouth communication intention: an application of the theory of planned behaviour. Journal of Hospitality and Tourism Research, 30(1), 95-116.

Cheng, S., Lam, T., \& Hsu, C. H. C. (2005). Testing the sufficiency of the theory of planned behaviour: a case of customer dissatisfaction responses in restaurants. International Journal of Hospitality Management, 24(4), 475-492.

Churchill, G. A. (1979). A paradigm for developing better measures of marketing constructs. Journal of Marketing, 16(1), 64-73.

Cockrill, A., Goode, M., \& Emberson, D. (2008). Servicescape matters - or does it? The special case of betting shops. Marketing Intelligence and Planning, 26(2), 189-206.

Cohen, E., \& Ben-Nun, L. (2009). The important dimensions of wine tourism experience from potential visitors' perception. Tourism and Hospitality Research, 9(1), 20-31.

De Vellis, R. F. (2003). Scale development: theory and applications. Thousand Oaks, California: SAGE Publications.

Dodd, T. H. (2000). Influences on cellar door sales and determinants of wine tourism success: results from Texas wineries. In, Hall, C. M., Sharpies, L., Cambourne, B., Macionis, N. (Eds.), Wine tourism around the world: development, management and markets. Oxford: Elsevier Science (pp. 136-149).

Dodd, T. H. (1995). Opportunities and pitfalls of tourism in a developing wine industry. International Journal of Wine Marketing, 7(1), 5-16.

Dodd, T. H., \& Gustafson, W. A. (1997). Product, environmental, and service attributes that influence consumer attitudes and purchases at wineries. Journal of Food Products Marketing, 4(3), 41-59.

Douglas, N., Douglas, N., \& Derrett, R. (2001). Special interest tourism: context and cases. Brisbane and Melbourne: John Wiley and Sons.

French, D., \& Hankins, M. (2003). Expectancy-value muddle in the theory of planned behaviour - and some proposed solutions. British Journal of Health Psychology, 8(1), 37 55.

Francis, J. J., Eccles, M. P., Johnston, M., Walker, A. E., Grimshaw, J. M., Foy, R., Kanner, E., Smith, L., \& Bonetti, D. (2004). Constructing questionnaires based upon the theory of planned behaviour: a manual for health services researchers. Newcastle upon Tyne: University of Newcastle upon Tyne, Centre for Health Services Research.

Fornell, C., \& Larker, D. F. (1981). Structural equation models with unobservable variables and measurement error: algebra and statistics. Journal of Marketing Research, 18(3), 382388.

Gammack, J. G. (2006). Wine tourism and sustainable development in regional Australia. In, Carlsen, J., Charters, S. (Eds.), Global wine tourism: research, management and marketing. Wallingford: $\mathrm{CAB}$ International.

Getz, D., \& Brown, G. (2006[a]). Critical success factors for wine regions: a demand analysis. Tourism Management, 27(1): 146-158.

Getz, D., \& Brown, G. (2006[b]). Benchmarking wine tourism development: the case of the Okanagan Valley, British Columbia, Canada. International Journal of Wine Business Research, 18(2), 78-97.

Getz, D., Dowling, R., Carlsen, J., \& Anderson, D. (1999). Critical success factors for wine tourism. International Journal of Wine Marketing, 11(3), 20-43.

Gill, D., Byslma, B., \& Ouschan, R. (2007). Customer perceived value in a cellar door visit: the impact on behavioural intentions. International Journal of Wine Business Research, 19(4), 257-275. 
Gonzalez, M. E. A., Comesana, L. R., \& Brea, J. A. (2007). Assessing tourist behavioural intentions through perceived service quality and customer satisfaction. Journal of Business Research, 60(2), 153-160.

Griffin, T., \& Loersch, A. (2006). The determinants of quality experiences in an emerging wine region. In, Carlsen, J., Charters, S., (Eds.), Global wine tourism: research, management and marketing. Wallingford: CAB International (pp. 153-60).

Hair, J. F., Babin, B. J., \& Anderson, R. E. (2010). Multivariate data analysis: a global perspective. New Jersey: Pearson Education.

Hall, C. M., Sharples, L., Cambourne, B., \& Macionis, N. (2002). Wine tourism around the world: development, management and markets. Auckland: Butterworth-Heinemann.

Han, H., Hsu, L., \& Sheu, C. (2010). Application of the theory of planned behaviour to green hotel choice: testing the effect of environmental friendly activities. Tourism Management, $31(3), 325-334$.

Heide, M., \& Grønhaug, K. (2006). Atmosphere: conceptual issues and implications for hospitality management. Scandinavian Journal for Hospitality and Tourism, 6(4), 271286.

Hernandez Maestro, R. M., Munoz Gallego, P. A., \& Santos Reuejo, L. (2007). The moderating role of familiarity in rural tourism in Spain. Tourism Management, 28(4), 951964.

Hoffman, D. L., \& Novak, T. P. (1996). Marketing in hypermedia computer-mediated environments: conceptual foundations. Journal of Marketing, 60(3), 50-68.

Hsu, C., \& Huang, S. (2012). An extension of planned behaviour model for tourists. Journal of Hospitality and Tourism Research, 36, 390-417.

International Organisation of Vine and Wine. (2013). Statistical report on world vitiviniculture. Paris, France.

Johnson, R., \& Bruwer, J. (2007). Regional brand image and perceived wine quality: the consumer perspective. International Journal of Wine Business Research, 19(4): 276-297.

Kim, W. G., \& Moon, Y. J. (2009). Customers' cognitive, emotional, and actionable response to the servicescape: a test of the moderating effect of the restaurant type. International Journal of Hospitality Management, 28(1), 144-156.

Koch, J., Martin, A., \& Nash, R. (2013). Overview of perceptions of German wine tourism from the winery perspective. International Journal of Wine Business Research, 25(1), 5074.

Kwortnik, R. J. (2008). Shipscape influence on the leisure experience. International Journal of Culture, Tourism and Hospitality Research, 2(4), 289-311.

Lam, T., \& Hsu, C. (2004). Theory of planned behaviour: potential travellers from China. Journal of Hospitality and Tourism Research, 28(4), 463-482.

Lee, T. H., \& Chang, Y. S. (2012). The influence of experiential marketing and activity involvement on the loyalty intentions of wine tourists in Taiwan. Leisure Studies, 31(1), 103-121.

Lee, Y., Lee, C., Lee, S., \& Babin, B. J. (2008). Festivalscapes and patrons' emotions, satisfaction, and loyalty. Journal of Business Research, 61(1), 56-64.

Lockshin, L., \& Corsi, A. M. (2012). Consumer behaviour for wine: a review since 2003 and future directions. Wine Economics and Policy, 1(1), 2-23.

Loda, M. D., Norman, W., \& Backman, K. F. (2007). Advertising and publicity: suggested new applications for tourism marketers. Journal of Travel Research, 45(3), 259-265.

Lucas, A. F. (2003). The determinants and effects of slot servicescape satisfaction in a Las Vegas hotel casino. The Gaming Research and Review Journal, 7(1), 1-20.

Marzo-Navarro, M., \& Pedraja-Iglesias, M. (2012). Critical factors of wine tourism. International Journal of Contemporary Hospitality Management, 24(2), 312-334. 
Marzo-Navarro, M., \& Pedraja-Iglesias, M. (2010). Are there different profiles of wine tourists? An initial approach. International Journal of Wine Business Research, 22(4), 349-361.

McGovern, P. (2003). Ancient wines: the search for the origins of viniculture. New Jersey: Princeton University Press.

Mitchell, R., Charters, S., \& Albrecht, J. N. (2012). Cultural systems and the wine tourism product. Annals of Tourism Research, 39(1) 311-335.

Mitchell, R., \& Hall, C. M. (2004). The post-visit consumer behaviour of New Zealand winery visitors. Journal of Wine Research, 15(1), 39-49.

Newman, A. J. (2007). Uncovering dimensionality in the servicescape: towards legibility. Services Industry Journal, 27(1), 15-28.

Oakes, S., \& North, A. C. (2008). Reviewing congruity effects in the service environment musicscape. International Journal of Service Industry Management, 19(1), 63-82.

O'Neill, M., Palmer, A., \& Charters, S. (2002). Wine production as a service experience: the effects of service quality on wine sales. Journal of Services Marketing, 16(4), 342-362.

Pan, F., Su, S., \& Chiang, C. (2008). Dual attractiveness of winery: atmospheric cues on purchasing. International Journal of Wine Business Research, 20(2), 95-100.

Peters, G. L. (1997). American winescapes: the cultural landscapes of America's wine country. USA: Westview Press.

Poitras, L., \& Getz, D. (2006). Sustainable wine tourism: the host community perspective. Journal of Sustainable Tourism, 14(5), 425-448.

Quintal, V. A., Lee, J. A., \& Soutar, G. N. (2010). Risk, uncertainty and the theory of planned behaviour: A tourism example. Tourism Management, 31(6), 797-805.

Quintal, V. A., \& Polczynski, A. (2010). Factors influencing tourists' revisit intentions. Asia Pacific Journal of Marketing and Logistics, 22(4), 554-578.

Reimer, A., \& Kuehn, R. (2005). The impact of servicescape on quality perception. European Journal of Marketing, 39(7), 785-808.

Roberts, L., \& Sparks, B. (2006). Enhancing the wine tourism experience: the customers' viewpoint. In, Carlsen, J., Charters, S. (Eds.), Global wine tourism: research, management and marketing. Wallingford: CAB International (pp. 47-55).

Ryu, K., \& Jang, S. S. (2007). The effect of environmental perceptions on behavioural intentions through emotions: the case of upscale restaurants. Journal of Hospitality and Tourism Research, 31(1), 56-72.

Sharples, L. (2002). Wine tourism in Chile... a brave new step for a brave new world. International Journal of Wine Marketing, 14(2), 43-53.

Skinner, A. (2000) Napa Valley, California: a model of wine region development. In, Hall, C. M., Sharpies, L., Cambourne, B., Macionis, N. (Eds.), Wine tourism around the world: development, management and markets. Oxford: Elsevier Science (pp. 283-296).

South Australian Wine Industry Association Incorporated (SAWIA). http://www.winesa.asn.au/

Sparks, B. (2007). Planning a wine tourism vacation? Factors that help to predict tourist behavioural intentions. Tourism Management, 28(5), 1180-1192.

Sparks, B. A., \& Pan, G. W. (2009). Chinese outbound tourists: understanding their attitudes, constraints and use of information sources. Tourism Management, 30(4), 483-494.

Steenkamp, J. E., \& van Trijp, H. C. (1991). The use of LISREL in validating marketing constructs. International Journal of Research in Marketing, 8(4), 283-299.

Tajfel, H. (1979). Individuals and groups in social psychology. British Journal of Social and Clinical Psychology, 18(2), 183-190.

Telfer, D. J. (2000). The northeast wine route: wine tourism in Ontario, Canada and New York State. In, Hall, C. M., Sharples, L., Cambourne, B., Macionis, N. (Eds.), Wine 
tourism around the world: development, management and markets. Auckland: Butterworth-Heinemann. 
Thomas, B., Quintal, V. A., \& Phau, I. (2011). Testing the winescape scale in Western Australia's wine country. In proceedings, Australian and New Zealand Marketing Academy Conference, November 2010, Perth, Australia: Australian and New Zealand Marketing Academy.

Thomas, B., Quintal, V. A., \& Phau, I. (2010[a]). Developing a scale that measures the winescape. In proceedings, Australian and New Zealand Marketing Academy Conference, November 2010, Christchurch, New Zealand: Australian and New Zealand Marketing Academy.

Thomas, B., Quintal, V. A., \& Phau, I. (2010[b]). Predictors of attitudes and intention to revisit a winescape. In proceeding, Australian and New Zealand Marketing Academy Conference, November 2009, Christchurch, New Zealand: Australian and New Zealand Marketing Academy.

Trepte, S. (2006). Social identity theory. In, Bryant, J., Varderer, P. (Eds.), Psychology of entertainment. New York: Routledge (pp. 255-271).

Wakefield K. L., \& Blodgett, J. G. (1999). Customer response to intangible and tangible service factors. Psychology and Marketing, 16(1), 51-68.

Wirtz, J., Mattila, A., \& Tan, R. (2007). The role of arousal congruency in influencing consumers' satisfaction evaluations and in-store behaviours. International Journal of Service Industry Management, 18(1), 6-24.

Yoon, Y., \& Uysal, M. (2005). An examination of the effects of motivation and satisfaction on destination loyalty: a structural model. Tourism Management, 26(1), 45-56. 


\section{Figure 1: Research model}

Winescape Attributes

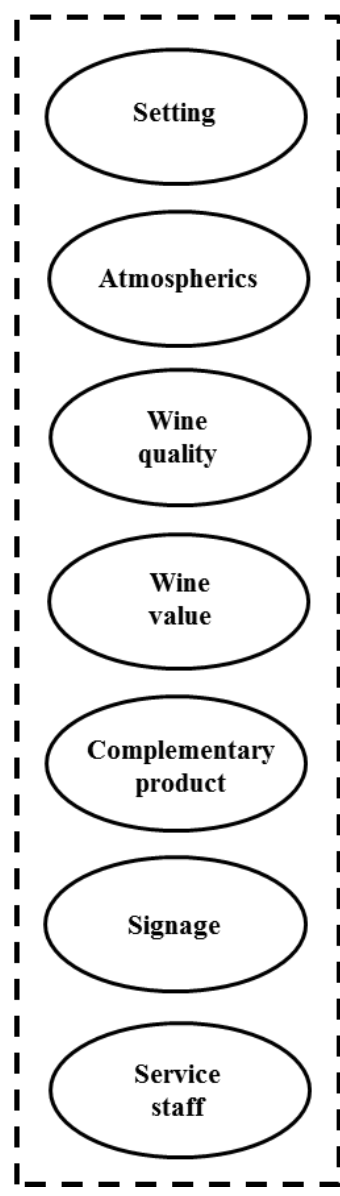

Theory of Planned Behaviour

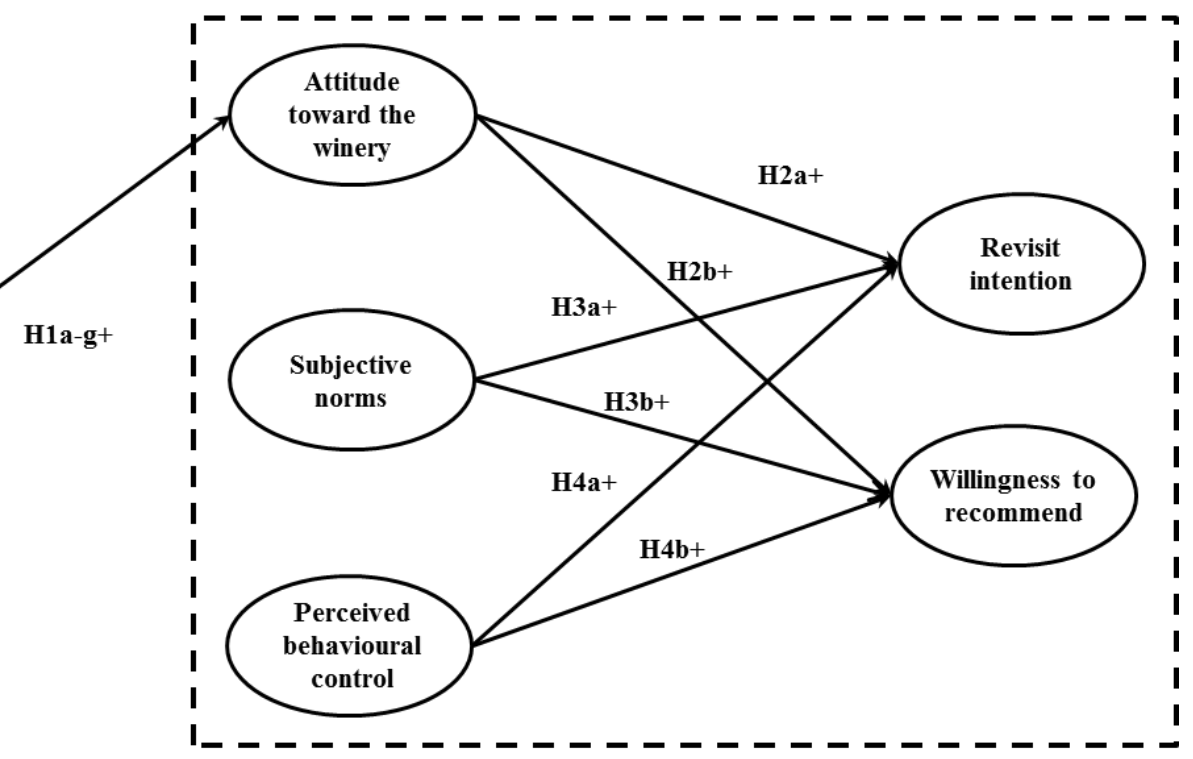


Picture 1: Swan Valley winery, Western Australia

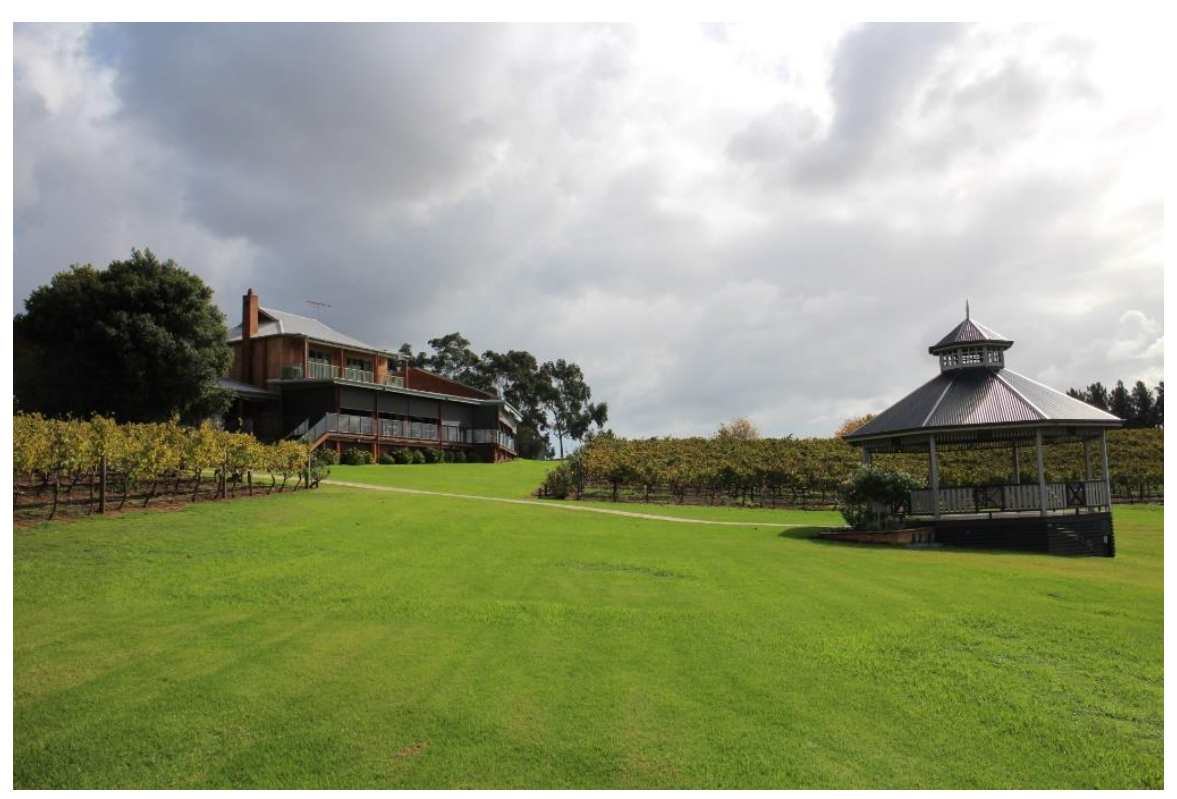


Picture 2: Barossa Valley winery, South Australia

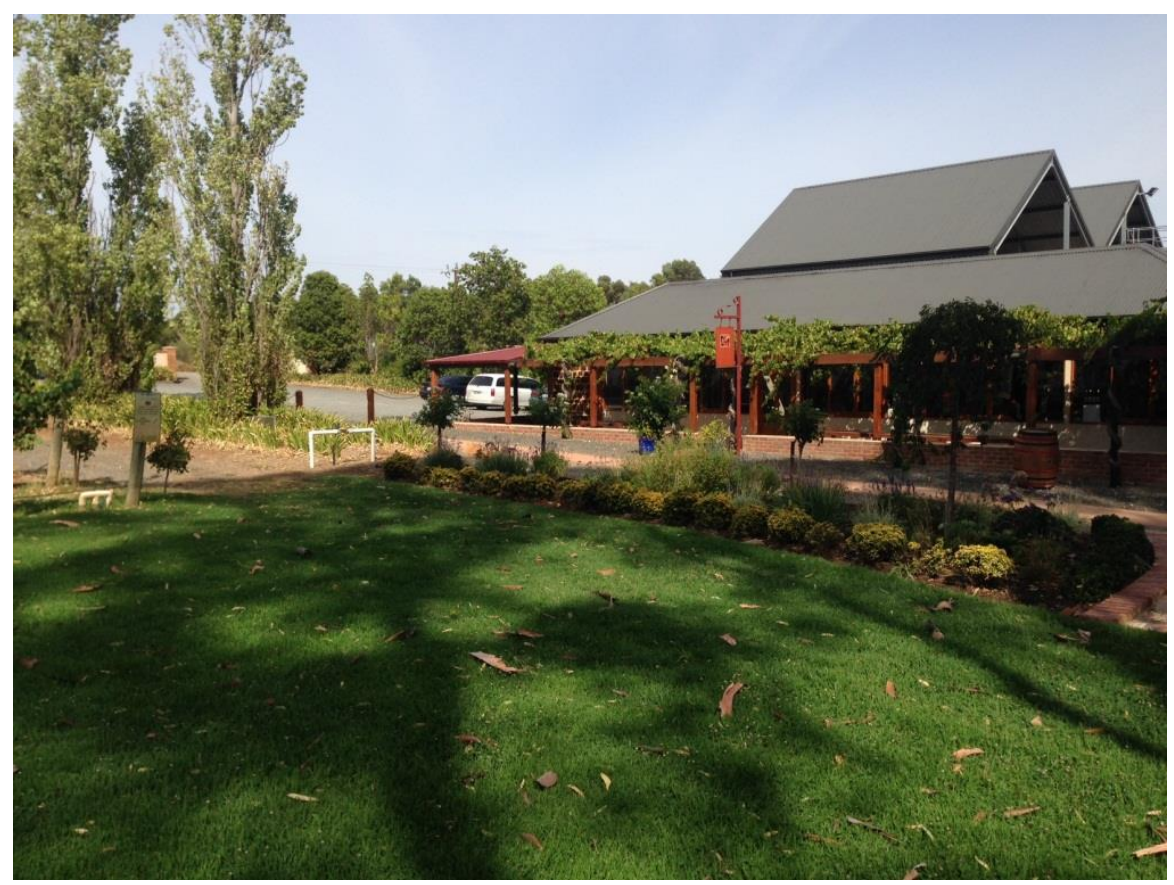


Table 1: Data collection and samples

\begin{tabular}{lcccc}
\hline Winery & $\begin{array}{c}\text { Study 1: } \\
\text { Swan Valley }\end{array}$ & $\begin{array}{c}\text { Study 2: } \\
\text { Yarra Valley }\end{array}$ & $\begin{array}{c}\text { Study 3: } \\
\text { Barossa Valley }\end{array}$ & $\begin{array}{c}\text { Study 4: } \\
\text { Napa Valley }\end{array}$ \\
\hline Number of responses & 329 & 302 & 321 & 345 \\
Number of responses screened out & 34 & 52 & 83 & 0 \\
Number of usable responses & 302 & 250 & 238 & 345 \\
Percentage of usable responses & 92 & 83 & 74 & 100 \\
\hline
\end{tabular}


Table 2: Composite reliabilities and average variance extracted for the winescape attributes and TPB constructs

\begin{tabular}{|c|c|c|c|c|c|}
\hline Study 1: Swan Valley & Items & $\mathbf{M}$ & SD & CR & AVE \\
\hline Setting & 3 & 6.18 & 0.79 & 0.86 & 0.68 \\
\hline Atmospherics & 3 & 4.43 & 1.20 & 0.90 & 0.75 \\
\hline Wine quality & 3 & 5.51 & 0.90 & 0.85 & 0.65 \\
\hline Wine value & 3 & 5.31 & 0.92 & 0.86 & 0.68 \\
\hline Complementary product & 3 & 4.42 & 1.14 & 0.81 & 0.59 \\
\hline Signage & 3 & 5.24 & 1.25 & 0.87 & 0.77 \\
\hline Service staff & 2 & 5.90 & 1.11 & 0.92 & 0.80 \\
\hline Subjective norms & 3 & 4.19 & 2.05 & 0.91 & 0.77 \\
\hline Attitude & 3 & 5.87 & 1.25 & 0.86 & 0.68 \\
\hline Perceived behavioural control & 3 & 6.09 & 1.05 & 0.82 & 0.63 \\
\hline Revisit intention & 3 & 5.21 & 1.85 & 0.91 & 0.77 \\
\hline Willingness to recommend & 3 & 5.89 & 1.19 & 0.95 & 0.87 \\
\hline Study 2: Yarra Valley & Items & $\mathbf{M}$ & SD & $\mathbf{C R}$ & AVE \\
\hline Setting & 3 & 5.85 & 0.87 & 0.87 & 0.68 \\
\hline Atmospherics & 3 & 5.30 & 1.08 & 0.88 & 0.71 \\
\hline Wine quality & 3 & 5.56 & 0.91 & 0.87 & 0.69 \\
\hline Wine value & 3 & 4.80 & 1.04 & 0.87 & 0.69 \\
\hline Complementary product & 3 & 5.14 & 0.97 & 0.71 & 0.45 \\
\hline Signage & 3 & 5.36 & 0.97 & 0.77 & 0.63 \\
\hline Service staff & 2 & 5.65 & 1.03 & 0.90 & 0.74 \\
\hline Subjective norms & 3 & 4.14 & 1.77 & 0.90 & 0.75 \\
\hline Attitude & 3 & 5.51 & 1.17 & 0.87 & 0.70 \\
\hline Perceived behavioural control & 3 & 5.55 & 1.17 & 0.87 & 0.69 \\
\hline Revisit intention & 3 & 5.09 & 1.57 & 0.89 & 0.72 \\
\hline Willingness to recommend & 3 & 5.39 & 1.25 & 0.93 & 0.82 \\
\hline Study 3: Barossa Valley & Items & M & SD & $\mathbf{C R}$ & AVE \\
\hline Setting & 3 & 6.03 & 0.94 & 0.87 & 0.70 \\
\hline Atmospherics & 3 & 5.12 & 1.28 & 0.92 & 0.80 \\
\hline Wine quality & 3 & 5.84 & 0.92 & 0.88 & 0.72 \\
\hline Wine value & 3 & 5.36 & 1.07 & 0.89 & 0.74 \\
\hline Complementary product & 3 & 4.58 & 1.52 & 0.87 & 0.70 \\
\hline Signage & 3 & 5.52 & 1.04 & 0.88 & 0.79 \\
\hline Service staff & 2 & 6.18 & 1.03 & 0.94 & 0.83 \\
\hline Subjective norms & 3 & 3.72 & 1.98 & 0.93 & 0.81 \\
\hline Attitude & 3 & 5.84 & 1.19 & 0.89 & 0.74 \\
\hline Perceived behavioural control & 3 & 5.88 & 1.27 & 0.86 & 0.68 \\
\hline Revisit intention & 3 & 4.77 & 1.74 & 0.88 & 0.71 \\
\hline Willingness to recommend & 3 & 5.55 & 1.22 & 0.96 & 0.89 \\
\hline Study 4: Napa Valley & Items & $\mathbf{M}$ & SD & CR & AVE \\
\hline Setting & 3 & 6.16 & 0.83 & 0.81 & 0.59 \\
\hline Atmospherics & 3 & 5.85 & 1.01 & 0.91 & 0.76 \\
\hline Wine quality & 3 & 6.16 & 0.84 & 0.84 & 0.63 \\
\hline Wine value & 3 & 5.61 & 1.10 & 0.88 & 0.72 \\
\hline Complementary product & 3 & 5.37 & 1.23 & 0.84 & 0.64 \\
\hline Signage & 3 & 5.79 & 1.05 & 0.88 & 0.79 \\
\hline Service staff & 2 & 6.19 & 0.86 & 0.88 & 0.71 \\
\hline Subjective norms & 3 & 4.95 & 1.65 & 0.91 & 0.77 \\
\hline Attitude & 3 & 6.34 & 0.83 & 0.85 & 0.65 \\
\hline Perceived behavioural control & 3 & 5.96 & 1.02 & 0.84 & 0.65 \\
\hline Revisit intention & 3 & 5.70 & 1.31 & 0.84 & 0.64 \\
\hline Willingness to recommend & 3 & 5.93 & 1.05 & 0.93 & 0.81 \\
\hline
\end{tabular}

Note: $\quad M=$ Mean, $S D=$ Standard deviation, $C R=$ construct reliability, $A V E=$ average variance extracted 
Table 3: Correlations for the winescape attributes and TPB constructs

\begin{tabular}{|c|c|c|c|c|c|c|c|c|c|c|c|c|}
\hline Study 1: Swan Valley & Setting & Atmospherics & Wine quality & $\begin{array}{l}\text { Wine } \\
\text { value }\end{array}$ & $\begin{array}{c}\text { Complementary } \\
\text { product }\end{array}$ & Signage & Service staff & $\begin{array}{l}\text { Subjective } \\
\text { norm }\end{array}$ & Attitude & $\begin{array}{c}\text { Perceived } \\
\text { behavioural } \\
\text { control }\end{array}$ & $\begin{array}{c}\text { Revisit } \\
\text { intention }\end{array}$ & $\begin{array}{c}\text { Willingness } \\
\text { to } \\
\text { recommend }\end{array}$ \\
\hline Setting & 1.00 & & & & & & & & & & & \\
\hline Atmospherics & 0.32 & 1.00 & & & & & & & & & & \\
\hline Wine quality & 0.48 & 0.28 & 1.00 & & & & & & & & & \\
\hline Wine value & 0.37 & 0.17 & 0.65 & 1.00 & & & & & & & & \\
\hline Complementary product & 0.27 & 0.35 & 0.31 & 0.29 & 1.00 & & & & & & & \\
\hline Signage & 0.16 & 0.15 & 0.24 & 0.32 & 0.33 & 1.00 & & & & & & \\
\hline Service staff & 0.36 & 0.14 & 0.37 & 0.35 & 0.35 & 0.21 & 1.00 & & & & & \\
\hline Subjective norm & 0.20 & 0.19 & 0.14 & 0.05 & 0.23 & 0.10 & 0.07 & 1.00 & & & & \\
\hline Attitude & 0.38 & 0.18 & 0.39 & 0.36 & 0.39 & 0.18 & 0.55 & 0.10 & 1.00 & & & \\
\hline Perceived behavioural control & 0.26 & 0.12 & 0.33 & 0.30 & 0.16 & 0.11 & 0.31 & 0.06 & 0.29 & 1.00 & & \\
\hline Revisit intention & 0.24 & 0.20 & 0.39 & 0.31 & 0.26 & 0.10 & 0.31 & 0.14 & 0.39 & 0.34 & 1.00 & \\
\hline Willingness to recommend & 0.44 & 0.28 & 0.41 & 0.33 & 0.33 & 0.19 & 0.49 & 0.24 & 0.44 & 0.33 & 0.46 & 1.00 \\
\hline Study 2: Yarra Valley & Setting & Atmospherics & Wine quality & $\begin{array}{l}\text { Wine } \\
\text { value }\end{array}$ & $\begin{array}{c}\text { Complementary } \\
\text { product }\end{array}$ & Signage & Service staff & $\begin{array}{l}\text { Subjective } \\
\text { norm }\end{array}$ & Attitude & $\begin{array}{c}\text { Perceived } \\
\text { behavioural } \\
\text { control } \\
\end{array}$ & $\begin{array}{c}\text { Revisit } \\
\text { intention }\end{array}$ & $\begin{array}{c}\text { Willingness } \\
\text { to } \\
\text { recommend }\end{array}$ \\
\hline Setting & 1.00 & & & & & & & & & & & \\
\hline Atmospherics & 0.29 & 1.00 & & & & & & & & & & \\
\hline Wine quality & 0.37 & 0.34 & 1.00 & & & & & & & & & \\
\hline Wine value & 0.28 & 0.22 & 0.58 & 1.00 & & & & & & & & \\
\hline Complementary product & 0.30 & 0.33 & 0.29 & 0.25 & 1.00 & & & & & & & \\
\hline Signage & 0.45 & 0.32 & 0.36 & 0.34 & 0.37 & 1.00 & & & & & & \\
\hline Service staff & 0.41 & 0.30 & 0.43 & 0.37 & 0.46 & 0.34 & 1.00 & & & & & \\
\hline Subjective norm & -0.08 & 0.07 & 0.02 & 0.12 & 0.12 & 0.01 & 0.11 & 1.00 & & & & \\
\hline Attitude & 0.26 & 0.25 & 0.31 & 0.19 & 0.36 & 0.16 & 0.48 & 0.11 & 1.00 & & & \\
\hline Perceived behavioural control & 0.27 & 0.14 & 0.37 & 0.27 & 0.37 & 0.29 & 0.37 & 0.07 & 0.30 & 1.00 & & \\
\hline Revisit intention & 0.13 & 0.17 & 0.35 & 0.19 & 0.25 & 0.17 & 0.28 & 0.07 & 0.51 & 0.25 & 1.00 & \\
\hline Willingness to recommend & 0.36 & 0.23 & 0.36 & 0.21 & 0.38 & 0.26 & 0.46 & 0.15 & 0.43 & 0.43 & 0.45 & 1.00 \\
\hline
\end{tabular}


Table 3: Correlations for the winescape attributes and TPB constructs (Continued)

\begin{tabular}{|c|c|c|c|c|c|c|c|c|c|c|c|c|}
\hline Study 3: Barossa Valley & Setting & Atmospherics & Wine quality & $\begin{array}{l}\text { Wine } \\
\text { value }\end{array}$ & $\begin{array}{c}\text { Complementary } \\
\text { product }\end{array}$ & Signage & Service staff & $\begin{array}{c}\text { Subjective } \\
\text { norm }\end{array}$ & Attitude & $\begin{array}{c}\text { Perceived } \\
\text { behavioural } \\
\text { control }\end{array}$ & $\begin{array}{c}\text { Revisit } \\
\text { intention }\end{array}$ & $\begin{array}{l}\text { Willingness } \\
\text { to } \\
\text { recommend }\end{array}$ \\
\hline Setting & 1.00 & & & & & & & & & & & \\
\hline Atmospherics & 0.57 & 1.00 & & & & & & & & & & \\
\hline Wine quality & 0.51 & 0.27 & 1.00 & & & & & & & & & \\
\hline Wine value & 0.34 & 0.33 & 0.61 & 1.00 & & & & & & & & \\
\hline Complementary product & 0.29 & 0.48 & 0.20 & 0.37 & 1.00 & & & & & & & \\
\hline Signage & 0.33 & 0.33 & 0.38 & 0.39 & 0.30 & 1.00 & & & & & & \\
\hline Service staff & 0.48 & 0.35 & 0.55 & 0.61 & 0.28 & 0.42 & 1.00 & & & & & \\
\hline Subjective norm & 0.14 & 0.09 & 0.12 & 0.10 & 0.13 & 0.12 & 0.11 & 1.00 & & & & \\
\hline Attitude & 0.42 & 0.39 & 0.44 & 0.50 & 0.40 & 0.36 & 0.56 & 0.23 & 1.00 & & & \\
\hline Perceived behavioural control & 0.25 & 0.27 & 0.21 & 0.24 & 0.18 & 0.26 & 0.22 & 0.02 & 0.19 & 1.00 & & \\
\hline Revisit intention & 0.36 & 0.27 & 0.36 & 0.31 & 0.25 & 0.19 & 0.27 & 0.33 & 0.40 & 0.15 & 1.00 & \\
\hline Willingness to recommend & 0.41 & 0.27 & 0.56 & 0.41 & 0.22 & 0.30 & 0.53 & 0.36 & 0.49 & 0.18 & 0.50 & 1.00 \\
\hline Study 4: Napa Valley & Setting & Atmospherics & Wine quality & $\begin{array}{l}\text { Wine } \\
\text { value }\end{array}$ & $\begin{array}{c}\text { Complementary } \\
\text { product }\end{array}$ & Signage & Service staff & $\begin{array}{c}\text { Subjective } \\
\text { norm }\end{array}$ & Attitude & $\begin{array}{c}\text { Perceived } \\
\text { behavioural } \\
\text { control }\end{array}$ & $\begin{array}{c}\text { Revisit } \\
\text { intention }\end{array}$ & $\begin{array}{c}\text { Willingness } \\
\text { to } \\
\text { recommend }\end{array}$ \\
\hline Setting & 1.00 & & & & & & & & & & & \\
\hline Atmospherics & 0.60 & 1.00 & & & & & & & & & & \\
\hline Wine quality & 0.55 & 0.48 & 1.00 & & & & & & & & & \\
\hline Wine value & 0.35 & 0.37 & 0.37 & 1.00 & & & & & & & & \\
\hline Complementary product & 0.41 & 0.59 & 0.34 & 0.52 & 1.00 & & & & & & & \\
\hline Signage & 0.44 & 0.44 & 0.44 & 0.35 & 0.49 & 1.00 & & & & & & \\
\hline Service staff & 0.42 & 0.40 & 0.62 & 0.39 & 0.34 & 0.46 & 1.00 & & & & & \\
\hline Subjective norm & 0.30 & 0.38 & 0.27 & 0.37 & 0.54 & 0.24 & 0.21 & 1.00 & & & & \\
\hline Attitude & 0.49 & 0.40 & 0.57 & 0.33 & 0.26 & 0.38 & 0.63 & 0.21 & 1.00 & & & \\
\hline Perceived behavioural control & 0.34 & 0.26 & 0.43 & 0.42 & 0.21 & 0.27 & 0.36 & 0.12 & 0.24 & 1.00 & & \\
\hline Revisit intention & 0.33 & 0.37 & 0.41 & 0.54 & 0.46 & 0.33 & 0.39 & 0.38 & 0.47 & 0.36 & 1.00 & \\
\hline Willingness to recommend & 0.53 & 0.50 & 0.64 & 0.42 & 0.37 & 0.41 & 0.62 & 0.42 & 0.62 & 0.43 & 0.51 & 1.00 \\
\hline
\end{tabular}




\section{Table 4: Standardised path coefficients and model fit}

\begin{tabular}{|c|c|c|c|c|c|}
\hline \multirow[b]{2}{*}{ Hypotheses } & \multicolumn{5}{|c|}{ Standardised Regression Weights } \\
\hline & $\begin{array}{c}\text { Pooled Sample } \\
(1-4) \\
(\mathrm{N}=1,127)\end{array}$ & $\begin{array}{c}\text { Study 1: } \\
\text { Swan Valley } \\
(\mathbf{N}=301)\end{array}$ & $\begin{array}{c}\text { Study 2: } \\
\text { Yarra Valley } \\
(\mathbf{N = 2 5 0 )}\end{array}$ & $\begin{array}{c}\text { Study 3: } \\
\text { Barossa Valley } \\
(\mathrm{N}=231)\end{array}$ & $\begin{array}{c}\text { Study 4: } \\
\text { Napa Valley } \\
(\mathrm{N}=\mathbf{3 4 5})\end{array}$ \\
\hline H1a: Setting $\rightarrow$ Atmospherics & $0.13^{\text {**** }}$ & 0.12 & -0.02 & 0.13 & $0.33^{* * * *}$ \\
\hline H1b: Atmospherics $\rightarrow$ Attitude & ns & ns & ns & ns & ns \\
\hline H1c: Wine quality $\rightarrow$ Attitude & $\mathrm{ns}$ & ns & ns & ns & $\mathrm{ns}$ \\
\hline H1d: Wine value $\rightarrow$ Attitude & $0.08^{*}$ & 0.08 & -0.03 & $0.17^{*}$ & 0.11 \\
\hline H1e: Complementary product $\rightarrow$ Attitude & $0.18^{* * *}$ & $0.19^{* *}$ & $0.24^{*}$ & $0.27^{* * *}$ & $-0.12^{*}$ \\
\hline H1f: Signage $\rightarrow$ Attitude & ns & ns & ns & ns & ns \\
\hline H1g: Service staff $\rightarrow$ Attitude & $0.42^{* * *}$ & $0.39^{* * *}$ & $0.37^{* * *}$ & $0.30^{* *}$ & $0.57^{* * *}$ \\
\hline H2a: Attitude $\rightarrow$ Revisit intention & $0.41^{* * *}$ & $0.35^{\text {*** }}$ & $0.51^{* * *}$ & $0.35^{* * *}$ & $0.45^{* * *}$ \\
\hline $\mathrm{H} 2 \mathrm{~b}:$ Attitude $\rightarrow$ Willingness to recommend & $0.41^{* * *}$ & $0.35^{* * *}$ & $0.33^{* * *}$ & $0.39^{* * *}$ & $0.60^{* * *}$ \\
\hline H3a: Subjective norm $\rightarrow$ Revisit intention & $0.20^{* * *}$ & $0.11^{*}$ & -0.01 & $0.28^{* * *}$ & $0.31^{* * *}$ \\
\hline H3b: Subjective norm $\rightarrow$ Willingness to recommend & $0.24^{* * *}$ & $0.23^{* * *}$ & 0.09 & $0.31^{* * *}$ & $0.30^{* * *}$ \\
\hline H4a: Perceived behavioural control $\rightarrow$ Revisit intention & $0.20^{* * *}$ & $0.27^{* * *}$ & $0.18^{* *}$ & 0.11 & $0.26^{* * *}$ \\
\hline H4b: Perceived behavioural control $\rightarrow$ Willingness to recommend & $0.24^{* * *}$ & $0.21^{* *}$ & $0.36^{* * *}$ & 0.12 & $0.22^{* * *}$ \\
\hline \multicolumn{6}{|l|}{ Model fit statistics } \\
\hline$\chi^{2}$ & 1361.40 & 787.35 & 709.98 & 563.70 & 725.19 \\
\hline$d f$ & 299 & 299 & 299 & 299 & 299 \\
\hline$\chi^{2} / d f$ & 4.55 & 2.63 & 2.38 & 1.89 & 2.43 \\
\hline$p$-value & 0.001 & 0.001 & 0.001 & 0.001 & 0.001 \\
\hline RMSEA & 0.06 & 0.07 & 0.07 & 0.06 & 0.06 \\
\hline GFI & 0.91 & 0.83 & 0.83 & 0.85 & 0.86 \\
\hline CFI & 0.95 & 0.92 & 0.90 & 0.95 & 0.94 \\
\hline NFI & 0.94 & 0.87 & 0.84 & 0.90 & 0.90 \\
\hline
\end{tabular}




\section{Appendix 1: Winescape and TPB scale items}

\begin{tabular}{|c|c|}
\hline Winescape Attributes & Winescape Items \\
\hline Setting & $\begin{array}{l}\text { There is a scenic outlook } \\
\text { The scenery is attractive } \\
\text { The landscape has a rural appeal }\end{array}$ \\
\hline Atmospherics & $\begin{array}{l}\text { The buildings have historic appeal } \\
\text { The architecture reflects a strong cultural heritage } \\
\text { The place has a sense of history }\end{array}$ \\
\hline Wine Quality & $\begin{array}{l}\text { The winery has reputable wines } \\
\text { The winery produces wines for which the region is renowned } \\
\text { The quality of the wine tasted is high }\end{array}$ \\
\hline Wine Value & $\begin{array}{l}\text { Wines sold at this winery offer value for money } \\
\text { The wines sold are within my spending budget } \\
\text { The retail price of wine at the cellar door is reasonable }\end{array}$ \\
\hline Complementary Product & $\begin{array}{l}\text { Adequate entertainment } \\
\text { Adequate art/gallery facilities } \\
\text { Sufficient local produce from the region on offer }\end{array}$ \\
\hline Signage & $\begin{array}{l}\text { Directional signage to the winery is clear } \\
\text { There is adequate signage }\end{array}$ \\
\hline Service Staff & $\begin{array}{l}\text { The winery has friendly staff } \\
\text { Staff are consistently courteous with guests } \\
\text { Staff provide individual attention }\end{array}$ \\
\hline TPB Constructs & TPB Items \\
\hline Attitude & $\begin{array}{l}\text { My attitude toward this winery is: } \\
\text { Bad-Good } \\
\text { Dissatisfied-Satisfied } \\
\text { Unenjoyable-Enjoyable }\end{array}$ \\
\hline Subjective Norms & $\begin{array}{l}\text { Most of the people important to me suggested I should visit this winery } \\
\text { I visited this winery after hearing recommendations from family/friends } \\
\text { I visited this winery since it is popular amongst my family/friends }\end{array}$ \\
\hline Perceived Behavioural Control & $\begin{array}{l}\text { Nothing prevented me from visiting this winery } \\
\text { Whether or not I visited this winery was entirely up to me } \\
\text { I had complete control over whether or not I visited this winery }\end{array}$ \\
\hline Revisit Intention & $\begin{array}{l}\text { My intention to revisit this winery in the next } 12 \text { months is: } \\
\text { Likely-Unlikely } \\
\text { Impossible-Possible } \\
\text { Certain-Uncertain }\end{array}$ \\
\hline Willingness to recommend & $\begin{array}{l}\text { I will suggest this winery to my family/friends as a place to visit } \\
\text { I will recommend the winery to anyone who seeks my advice } \\
\text { I am happy to encourage family/friends to visit this winery }\end{array}$ \\
\hline
\end{tabular}

